\title{
Macroeconomic News 'Surprises' and the Rand/Dollar Exchange Rate
}

\author{
Johannes Fedderke $^{1}$ and Philippe Flamand ${ }^{2}$
}

Working Paper Number 18

${ }^{1}$ School of Economics, University of Cape Town

${ }^{2}$ School of Economics, University of Cape Town 


\title{
Macroeconomic News 'Surprises' and the Rand/Dollar \\ Exchange Rate \\ Johannes Fedderke and Philippe Flamand* \\ March 2005
}

\begin{abstract}
ABSTRACT: Economic theory in the context of floating exchange rates has focussed on underlying medium and long term direction of exchange rate movements. Daily volatility is less well understood. One theory that offers an explanation for short term exchange rate movements is that of the efficient market hypothesis or EMH. Its application to the forex market allows exchange rate movements to be understood as the reaction of traders to relevant news. In an efficient market traders react to news and specifically to surprise news events which necessitate a re-evaluation of the currency value. We test for the validity of this hypothesis in the context of the daily rand/dollar forex market over a three year period, adding an emerging market case to the literature. We test the significance of macroeconomic news surprises -measured by the difference between actual and forecast data - in driving daily exchange rates. We find that surprises in both real and nominal variables cause a statistically significant reaction in the exchange rate. The results support an asymmetry between news of different origin as only surprises that originate in the U.S. prove significant. Good news also seems to receive greater attention from traders than bad news in our sample. Finally, we find that the statistical significance of variables is time-varying.

KEYWORDS: Daily exchange rate, Macroeconomic news surprises and efficient market hypothesis.
\end{abstract}

\section{Introduction}

The economic theory of exchange rates focuses on the long run. Standard explanations of the determination of the exchange rate rest on the law of one price driving trade flows, as evidenced by absolute or relative purchasing power parity (PPP), determinants of capital flows in the theory of uncovered interest parity (UIP), and a more general macroeconomic equilibrium approach in fundamental equilibrium exchange rate theory (FEER). All these approaches have in common

${ }^{*}$ School of Economics, University of Cape Town 
that the exchange rate is viewed as the outcome of equilibrium relationships that hold in the long run. Empirical evidence is available to suggest that these theories, or some combination of them, does indeed hold, provided only that the relationships are sought in the underlying long run structure of the data rather than short run dynamic movements. ${ }^{1}$

This leaves unresolved our understanding of the short run. Yet in the context of trading on foreign exchange markets, particularly in the relatively volatile emerging market currencies, the long run structure underlying exchange rate determination is of little succour, especially given the length of time that is often required for PPP, UIP or FEER to manifest itself.

We are then left with the question of whether it is possible to develop a systematic account of short run movements in exchange rates? One suggestion has come from a variant of the efficient markets hypothesis (EMH). Both Engel and Frankel (1985) and Ito and Roley (1986) noted in an examination of the US dollar that surprise events in a number of specific economic variables, deviations between prior market expectations and the actual event observed, were able to affect a change in US exchange rates. The underlying presumption is that all available information had already been factored into the price of the US currency by prior trades, such that movement in the price would purely be the result of new information entering the market - hence the impact of surprise events. ${ }^{2}$

A sequence of subsequent studies, investigating a number of different exchange rates, has provided support for the hypothesis that surprise events are able to move exchange rates. ${ }^{3}$ Significant exten-

\footnotetext{
${ }^{1}$ Famously, Johansen and Juselius (1992) demonstrated the operationalization of the VECM estimation strategy which distinguishes clearly between long run equilibrium relationships and short run dynamics on the estimation of a model that combined PPP and UIP theory for the UK.

${ }^{2}$ The link to Fama $(1970,1991)$ efficient markets is immediate.

${ }^{3}$ See Almeida et al (1998), Andersen and Bollerslev (1998), Edison (1996), Faust et al (2003), Galati and Ho (2003), Harris and Zabka (1995), Pearce and Solakoglu (2003), Prast and de Vor (2001).
} 
sions have been findings suggesting that the impact of surprises may be time-varying in the sense that surprise events in specific variables may be important in some time periods but not others, ${ }^{4}$ that there may be asymmetries between good and bad news events, ${ }^{5}$ between US and other country news events, ${ }^{6}$ between economic and political news events, ${ }^{7}$ between real and nominal variables, ${ }^{8}$ and that specific variables may carry more weight than others. ${ }^{9}$ An important estimation issue relates to the frequency of observations employed, with results proving stronger the higher the frequency of the data employed. ${ }^{10}$

To date an examination of the impact of news events to emerging market economies has been restricted. ${ }^{11}$ In this paper we examine the extent to which news events can explain movements in currency of one of the more important emerging markets - South Africa. The application is particularly apposite, since the South African currency has been particularly volatile over the course of the 1990's, to an extent that precludes reliance on PPP, UIP or FEER in explaining the strength of the movement observed. The past decade has seen the rand weaken $15.6 \%$ to the dollar in 1996, recover, collapse once more in 1998, plunge to a record low of 13.85 to the dollar in 2001(ABSA, 2001) and now rise back to its current strength of around 6 to the dollar in 2004. ${ }^{12}$ The Bank for International Settlements found that

\footnotetext{
${ }^{4}$ See Almeida et al (1998), Andersen and Bollerslev (1998), Edison (1996), Galati and Ho (2001), and Ito and Roley (1996).

${ }^{5}$ See Galati and Ho (2001).

${ }^{6}$ See Almeida et al (1998), Andersen and Bollerslev (1998), Faust et al (2003), Galati and Ho (2001).

${ }^{7}$ See Prast and de Vor (2001), Galati and Ho (2001).

${ }^{8}$ See Andersen and Bollerslev (1998), Edison (1996), Engel and Frankel (1985).

${ }^{9}$ For instance Harris and Zabka (1985) point to the importance of US employment data, and Andersen and Bollerslev (1998) to the importance of real variables in the US, and nominal variables in Germany.

${ }^{10}$ See Almeida et al (1998), Andersen and Bollerslev (1998), Pearce and Solakoglu (2003).

${ }^{11}$ We have not been able to locate a study which does so.

${ }^{12}$ Part of the reason for the volatility was contagion from the Asian crises of the late 1990's. See the discussion in Fedderke (2004). But this is only part of the
} 
turnover in the rand currency market greatly exceeded that in other emerging markets similar to South Africa highlighting its volatility (Garrow, 2004). Developing an understanding of the volatility of the rand remains a pressing task, extending to a government inquiry (The Myburgh Commission).

The question in this paper is whether macroeconomic news 'surprises' account for some of the rand/dollar volatility - particularly since Aron and Ayogou (1997) find inefficiencies in the South African exchange rate market. The exchange rate under consideration in this paper is the daily rand/dollar rate from June 2001 to June 2004 over which time the rand has strengthened, not without fluctuations, from 8.021 in June 2001 to 6.16 of June 2004 as seen in Figure 1.

Section 2 gives a brief description of the data used. In section 3 we present our results, and section 4 concludes.

\section{Data}

The data used in this investigation includes a number of economic variables over a time period of 37 months. The dependent variable used is the log change in the daily rand/dollar exchange rate where the daily exchange rate is given by the rate at noon in New York. This measure is used to allow all information or data releases to have their impact from traders in both South Africa and the U.S. The explanatory variables represent a number of different economic indicators suggested by the literature, subject to availability.

Variables cover events both for the USA and for South Africa, and for both real and nominal variables. Macroeconomic data announcements in South Africa were represented by the CPIX which is the South African Reserve Banks (SARB's) indicator of domestic inflation on a monthly basis; the Producer Price Index (PPI) which gives a measure of monthly inflation growth in goods used for production; the Repo rate which is a proxy for interest rates and is adjusted at

story, and much remains to be done in trying to understand short term movement in the South African currency. 
non-standardized intervals by the Monetary Policy Committee; GDP which gives an indication of the economy's growth on a quarterly basis, the money supply (M3) calculated by Stats SA on a monthly basis and the trade deficit/surplus each month. The data releases originating in the U.S. were represented by the Consumer Price Index (CPI) which is a measure of monthly inflation; monthly PPI; the Federal Funds rate which serves a purpose similar to the South African Repo; non-farm payrolls which indicates the creation of jobs each month; industrial production which gives a measure of monthly economic activity and the trade deficit/surplus.

Table 1 provides a summary of the variables included.

Although not strictly comparable, the variables control for similar economic fundamentals covering both real and nominal variables between South Africa and the USA. CPIX and CPI measure consumer inflation in the two countries; the two PPI measures are directly comparable; the Federal Funds rate and the Repo both represent central bank interest rate decisions; industrial production, non farm payrolls and GDP measured economic activity/growth; the trade surplus/deficit gives a measure of trade activity for both countries; and M3 was included to give an indication of money supply growth in South Africa.

For all of these explanatory variables the size of a news 'surprise' is measured as the difference between the markets forecast and the actual data announced. Forecast values were taken from the Reuters consensus forecast for each event and from the Dow Jones-CNBC poll when a Reuter's forecast was not available. These forecasts were used as a proxy for the markets' forecast as a whole. ${ }^{13}$

Dummy variables identified "good" and "bad" news events. While for most variables a positive surprise meant good news whereas a negative surprise meant bad news, in the case of inflation measured by

\footnotetext{
${ }^{13}$ The authors are grateful to Donovan Byrne and Factiva.com for access to historic Reuters and Dow Jones articles as well as exchange rate data free of charge. Actual data announcements were taken from the same sources via the website of Factiva.com.
} 
CPI, CPIX, PPI and M3 a positive surprise is classified as good/bad depending on whether a country faces inflation or disinflation. ${ }^{14}$ On certain inflation and interest rate events, classification as good or bad required reference to financial press discussions surrounding the news release. All other variables were good news if they were greater than expected and bad news if less than expected. This gave a total of 24 dummies - a good and a bad for each variable employed. Object of the construct is to test for asymmetries between the exchange rate impact on good and bad news events.

Dummy variables were also constructed for country specific good or bad news events, regardless of which variable was the source of the news. Object of the construct is to test for asymmetries between the country source of good and bad news events.

All the data employed in the study is stationary. Table 2 reports the relevant Augmented Dickey Fuller statistics. The dependent variable is stationary since it is the log change in the daily exchange rate. The macroeconomic 'surprise' variables are stationary by construction, since they are the difference between forecast and actual values.

\section{Results}

Given the stationarity of our data, we estimate by Ordinary Least Squares (OLS). Object of the investigation is to establish whether macroeconomic news 'surprises' are significant as a determinant of daily rand/dollar exchange rate changes.

We begin by considering the impact of the various macroeconomic 'surprise' variables - the difference between actual and forecast data for each variable at that point in time - on the daily log change in the rand/dollar exchange rate. Specifically:

$$
\Delta \ln \phi_{t}=\alpha+\sum_{i=1}^{12} \beta_{i}\left[X_{i, t}-E_{t}\left(X_{i, t}\right)\right]+u_{t}
$$

\footnotetext{
${ }^{14}$ Given the weak empirical link between M3 and inflation, in this case the interpretation of the surprise event requires corresponding modulation.
} 
where $\delta_{t}$ denotes the rand - dollar exchange rate at time $t$, the $X_{i}$ represent the twelve sources of macroeconomic news surprises detailed in the data section above, and $E_{t}$ denotes the expectations operator at time $t$.

Results are reported in column 1 of Table 3.

The results indicate that relevant news events for the rand/dollar exchange rate are US-based only, given the absence of statistical significance on all South African news events. Both real (industrial production) and nominal (consumer and producer price inflation) news events prove to impact the exchange rate. Thus we find evidence of the country news asymmetry that has been reported for developed countries to transfer to the emerging market case, though the asymmetry does not extend to the distinction between real and nominal variables. News 'surprises' in countries such as Japan (see Pearson and Solokoglu, 2003), Germany (see Almeida et al (1998), Andersen and Bollerslev (1998), Pearson and Solokoglu, (2003)) and the Euro area (see Prast and De Vor, (2001), Gelati and Ho (2001)) have been insignificant in explaining daily exchange rate movements for much of the time, while US news events have had a stronger impact. Given the considerably smaller size of the South African economy relative to any of these comparators, our finding of a similar asymmetry with respect to the USA is not surprising.

Given the relatively poor goodness of fit statistics, the results do not suggest that news events captured for this study do not provide a comprehensive depiction of short run dynamics of the rand - dollar exchange rate.

The positive coefficient on U.S. CPI implies that if consumer inflation rises, the dollar appreciates relative to the rand. The standard prior is to judge higher inflation as bad news. One possible explanation of the counterintuitive finding may be expectations of interest rate hikes on announcements of higher than expected inflationary pressure. This interpretation is supported by the Engel and Frankel (1985) and Ito and Roley (1986) findings that greater than expected money supply figures led to an appreciation of the dollar. A second possible 
explanation would be that in the recent U.S. recession, which falls substantially within sample for our study, inflation may have been interpreted as a sign of expanding economic activity, and thus interpreted as favourable rather than negative.

The more pressing question in the face of these results is whether there exists a systematic account for the relatively small number of variables in which news events prove statistically significant to movement in the rand/dollar exchange rate. We examine a number of possible reasons.

First, over much of the sample period used there has been a steady rand appreciation - which can be seen in Figure $1 .^{15}$ Hence on any given day there would have been a tendency for the exchange rate to decrease, no matter what 'surprises' occurred - in effect the dependent variable is biased toward negative values, since it is the first difference of the exchange rate. Currently none of the explanatory variables capture this effect. In order to control for this possibility, columns (2a) through (2c) of Table 3 control for the break in the series at $20 / 12 / 2001$, at which the sharp depreciation of the rand reversed, by means of a dummy, ${ }^{16}$ by a trend variable, and both dummy and trend. While there is some improvement in the goodness of fit measures, and certainly support for the presence of a break in the series at $20 / 12 / 2001$, the central conclusion we drew from the results of column (1) of Table 3 stand. The same three nominal and real US variables remain significant (though their standard errors decline), thus confirming the country asymmetry of news surprises for the rand/dollar rate, without altering the size of the economic impact of the news events.

Second, we test for the possibility that exchange rate movements may be non-linear in surprises - specifically that large surprises may have a more substantial impact than small - potentially even ignoring news that is only marginally different from that expected. In order to

\footnotetext{
${ }^{15}$ Possibly due to the high interest rate differentials with the U.S. and resultant capital inflows into South Africa.

${ }^{16}$ Which loads on the appreciation
} 
test for this possibility each 'surprise' was squared while maintaining its original positive or negative sign, and included in the regression. Results, with squared variables and a combination of squared and linear variables, are reported in Column 1 of Table 4. While goodness of fit again increases marginally, the results lend little support to the hypothesis that markets react disproportionately to large surprises. Once again PPIUS and IND are the only variables significant at the $5 \%$ level whilst CPIUS has become insignificant even at the $10 \%$ level. The results are again consistent with the initial findings of country asymmetry (reaction to US, not SA news events), though no asymmetry between real and nominal news emerges.

As a third possibility we consider the suggestion of market inefficiency in rand forex trading, contained in Aron and Ayogou (1997). We test for this through the introduction of lags into the estimation. Where markets are efficient, reaction to news surprises should be immediate, not delayed. Under market efficiency lags of explanatory variables should therefore be strictly insignificant statistically. In Table 4, Coluums (2a) and (2b) we introduce single and three period lags of each explanatory variable into the specification. ${ }^{17}$ Results indicate that CPIUS impacts on the exchange rate three days after the 'surprise' at the 5\% level and two days after the 'surprise' at the $10 \%$ level of significance while the contemporaneous effect is now insignificant. PPIUS remains significant two days after the 'surprise' with the economically correct sign and TRADESA was significant with the theoretically correct sign on its coefficient two days after the data 'surprise'. All other variables and their lags, other than contemporaneous PPIUS and IND, were insignificant. The significance of lags of up to 72 hours after news events are consistent with the Aron and Ayogou (1997) finding of market inefficiency. Certainly the finding is at odds with strong EMH expectations.

As a fourth consideration we examine whether the international

\footnotetext{
${ }^{17}$ Recall that data is daily. We tested for numerous alternative lag structures, without obtaining substantively different results. Full results are available from the authors on request.
} 
finding of time-varying impact of news events is corroborated on the rand - dollar rate. To do so, we estimated equation (1) over shorter time periods of approximately 12 months, to test whether traders react to different variables over time. Results confirm the international findings. Consider the evidence of Table 5.In Columns (1a) through (1c) we report results for the $1 / 6 / 2001-1 / 11 / 2002,1 / 6 / 2002-1 / 6 / 2003$ and $1 / 6 / 2003-30 / 6 / 2004$ time periods respectively. IND is significant at the $1 \%$ level in only the first and second time periods whilst being insignificant in the last even at the $10 \%$ level. Similarly for U.S. PPI, which is only significant at the $1 \%$ level in the second time period.

The second period also shows U.S. CPI and TRADEUS as significant. In the final time period no variable is significant, suggesting a total insignificance of economic data 'surprises' in driving daily exchange rates.

A final possibility we considered by way of explanation of the relative insignificance of news events in explaining changes in the rand dollar rate, was that the frequency of our data may simply not be high enough. A number of international studies have been conducted on data at minute frequency, rather than daily data, and noted improved results under the higher frequency. ${ }^{18}$ Unfortunately, the present study was unable to source data of a significantly higher frequency. While we did examine results that introduced US opening, US noon, and US closing rand/dollar rates, results did not change significantly from those reported above. ${ }^{19}$ Testing the hypothesis on higher frequency data thus remains a task for future research.

Thus far our results have pointed to two asymmetries in the impact of news events. First, US news appears to impact the rand/dollar rate, while SA news does not, and second the impact of news events may be time-varying. By contrast, we have not found evidence of an asymmetry between nominal and real variables.

As a final analytical step we address the question of whether there

\footnotetext{
${ }^{18}$ See Almeida et al (1998), Andersen and Bollerslev (1998), Pearce and Solakoglu (2003).

${ }^{19}$ Full results are available from the authors on request.
} 
exists an asymmetry between good and bad news events for the rand dollar rate. Estimation was under the inclusion of a good and bad news dummy for each variable over the entire 37 -month period. Results are reported in column 3 of Table 4 . Only good news about U.S. industrial production was significant in explaining exchange rate fluctuations at the $5 \%$ level. Good news about the SA Repo was significant at the $10 \%$ level, with better than expected interest rate decisions leading to rand appreciation. ${ }^{20}$ The evidence thus does suggest an additional asymmetry to news events affecting the rand/dollar rate. Good news appears to impact the rate more dramatically than does bad news at least over the sample period under consideration.

As a further extension we also considered country-specific good and bad news events, with dummies for good and bad news events that emerge for either the US or SA, regardless of the variable that was the source of the news. Results are reported in Column (2a) of Table 5. Only US good news on macroeconomic variables possibly influences the daily rand/dollar exchange rate at the $10 \%$ level over the $37-$ month period. The coefficient is theoretically consistent, suggesting that US good news leads to dollar appreciation. None of the other country specific news types are significant.

In estimation, we further estimated the specification over successive six-month periods. ${ }^{21}$ Results, in columns (2b) to $(2 \mathrm{~g})$ of Table 5 , indicate that the impact of news events may well be time-varying. In the first, second, third, fifth and sixth periods none of the dummies were statistically significant. In the fourth time period U.S. good news

\footnotetext{
${ }^{20}$ Recall that the definition of "good" and "bad" here was event-specific, and relied on a careful consideration of prevailing market perceptions at the time of the event. Running the good/bad news regression over the shorter frequency exchange rate data we constructed, did add good news about the SA money supply and good news about non-farm payrolls to the list of significant variables though it renders good news about U.S. industrial production insignificant. This was one instance where results were marginally affected by the use of slightly higher frequency data.

${ }^{21}$ These thus cover the $1 / 6 / 2001-30 / 12 / 2001,1 / 1 / 2002-30 / 6 / 2002,1 / 7 / 2002$ $30 / 12 / 2002, \quad 1 / 1 / 2003-30 / 6 / 2003, \quad 1 / 7 / 2003-30 / 12 / 2003,1 / 1 / 2004-30 / 6 / 2004$ time periods.
} 
was significant at the $1 \%$ level with the intuitively plausible implication of rand depreciation. In the same period South African good news was associated with rand appreciation, significant at the $10 \%$ level.

\section{Conclusion and Evaluation}

This study considers the impact of macroeconomic news events on daily changes in the rand/dollar exchange rate.

We find that news events do impact on the exchange rate.

Asymmetries in the relationship between news and exchange rate movements are prevalent however. First, US news events impact the rate in more variables, in more time periods, and with greater strength than do South African news events. In fact, we find very little evidence of South African news having any significance on the daily rand/dollar rate whatsoever. Second, good news appears to impact the exchange rate statistically more strongly than bad news - though again this has a preponderance of US rather than SA news events. Third, the impact of news events is time-varying. The news events that impact on the markets change over time - suggesting that traders at any given time pay closer attention to some specific variables (which vary over time), rather than all potentially relevant news. The one dimension in which we do not find an asymmetry, is between real and nominal variables. We find that both real (industrial production) and nominal (inflation rate) variables impact on the rand/dollar rate, bearing in mind that these are US, not SA news events.

The inefficiency implied by the time varying impact of news events, finds further corroboration. Introduction of lagged news events into estimation suggested that the exchange rate may react to news events up to 72 hours after their occurrence. The implication is that the extent of market efficiency in the rand/dollar forex trade is perhaps somewhat less than that required for a straightforward confirmation of the EMH.

The impact of news events on the South African exchange rate thus comes with qualification. Certainly news events, while signifi- 
cant in some dimensions, are not the only determinants of changes in the rand/dollar rate - goodness of fit remained low throughout the estimations reported for this study - and the evidence supporting the presence of market inefficiency suggests that structural impediments to efficient adjustment of the exchange rate may exist in South African forex markets.

Equally, however, work on higher frequency data than that which was available for this study, remains as a topic for future research to shed additional light on the extent of market efficiency in the South African foreign exchange markets.

\section{References}

ABSA Group Limited, 2002, The Demise of The South African Rand, Economic Perspective, First Quarter 2002.

Almeida, A., Payne, R., Goodhart, C., 1998, The effects of macroeconomic news on high-frequency exchange rate behaviour, Journal of Financial and Quantitative Analysis, 33, 383-408.

Andersen, T. and Bollerslev, T., 1998, Deutsche Mark-Dollar volatility: Intraday activity patterns, Macroeconomic announcements, and longer run dependencies, Journal of Finance, 53(1).

Aron, J. and Ayogu, M., (1997), Foreign exchange market efficiency tests in Sub-Saharan Africa, Journal of African Economies, 6(3), 150-92.

Edison, H., 1996, The reaction of exchange rates and interest rates to news releases, FRB International Finance Discussion Papers no. 570 .

Engel, C. and Frankel, J., 1982, Why Money Announcements Move Interest Rates: An answer From The Foreign Exchange Market, NBER Working Paper no. 1049, National Bureau of Economic Research. 
Fama, E.F., 1970, Efficient Capital Markets: a Review of Theory and Empirical Work, Journal of Finance, 25(2).

Fama, E.F., 1991, Efficient Capital Markets II, Journal of Finance, $46,1575-1617$.

Faust, J., Rogers, J., Wang, S. and Wright, J., 2003, The highfrequency response of exchange rates to macroeconomic announcements, FRB International Finance Discussion Papers no. 784.

Fedderke, J.W., 2004, Was the Asian Financial Crisis a Transmission of Shocks Through Fundamental Links Between Countries, or a Case of Pure Contagion?: Comparing Evidence from Alternative Measures of Contagion, University of Cape Town, Mimeo.

Galati, G. and Ho, C., 2001, Macroeconomic News and the euro/dollar exchange rate, Bank of International Settlements, Working Papers no 105.

Garrow, C., 2004, Red Rubber Band, Financial Mail, 30 January 2004.

Harris, E., and Zabka, N., 1995, The Employment Report and the Dollar, Current Issues in Economics and Finance, 1(8), Federal Reserve Bank of New York.

Johansen, S., and Juselius, K., 1992, Testing structural hypotheses in a multivariate cointegrating analysis of the PPP and the UIP for UK, Journal of Econometrics, 53, 211-44.

Ito, T. and Roley, V., 1986, News from the U.S. and Japan: Which moves the yen/dollar exchange rate?, NBER Working Paper no. 1853, National Bureau of Economic Research.

Pearce, D. and Solakoglu, N., 2003, Macroeconomic News and Exchange Rates, Mimeo: ??? http://www4.ncsu.edu/unity/users/d/dkpearce/www/exchnews1126.pdf 
Prast, H and De Vor, M., 2001, Investor Reactions to News: an analysis of the euro/dollar exchange rate, DE Nederlandsche Bank, Directorate supervision-Monetary and Economic Policy Department, Research series supervision no. 38-MEB series no 2001-06.Variable ADF Test Statistic Critical Value (5\%). 
Figure 1: Daily Rand/Dollar exchange rate from June 2001 to June 2004

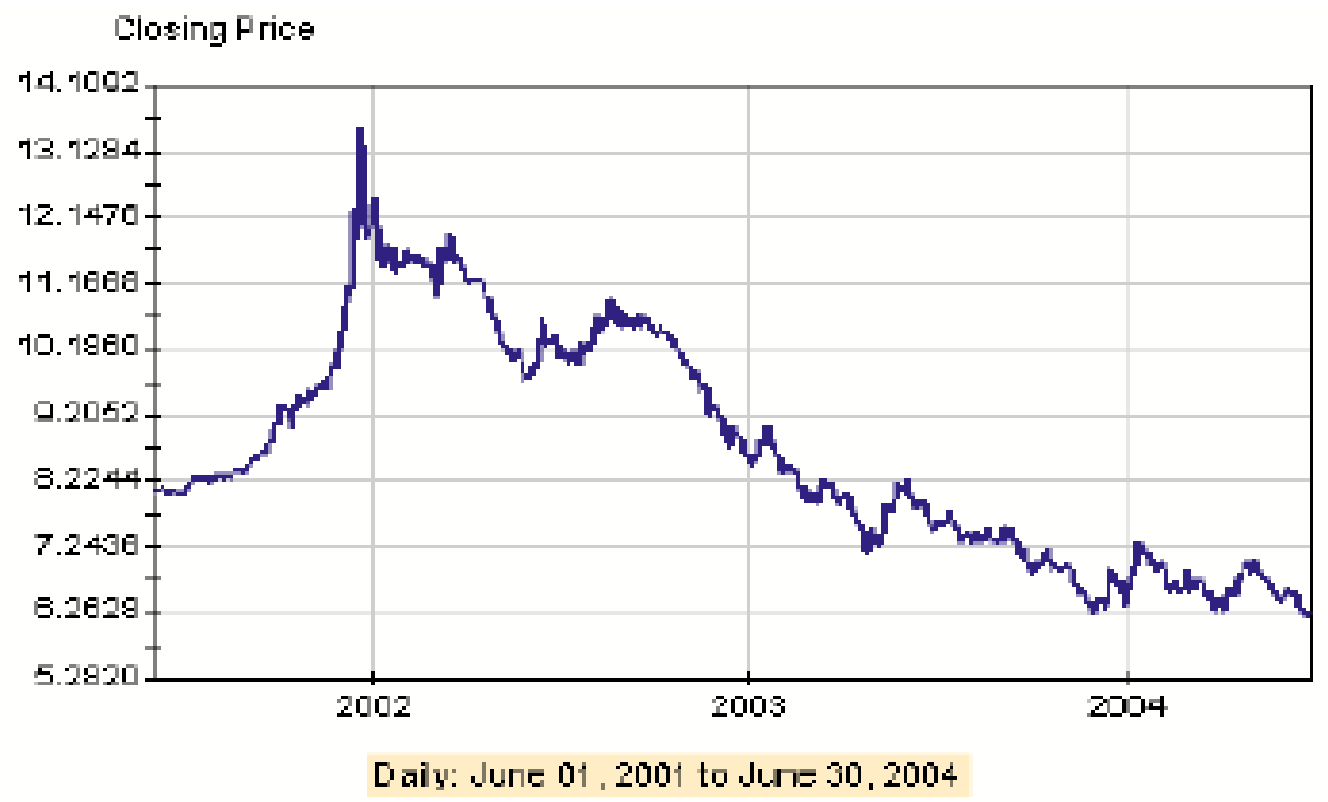

Source: SunGard Fomerdata (Trade ine) 
Table 1: Macroeconomic Variables

\begin{tabular}{|c|c|c|c|c|c|c|c|}
\hline $\begin{array}{l}\text { Country } \\
\mathrm{n} / \mathrm{a}\end{array}$ & $\begin{array}{l}\text { Variable } \\
\text { DLNER }\end{array}$ & $\begin{array}{l}\text { Description } \\
\text { Change: } \\
\text { Rand/Dollar } \\
\text { Exchange Rate }\end{array}$ & $\begin{array}{l}\text { 'Surprises' } \\
\text { n/a }\end{array}$ & $\begin{array}{l}\text { Mean } \\
-.3173 E-3\end{array}$ & $\begin{array}{l}\text { Standard Dev. } \\
.012860\end{array}$ & $\begin{array}{l}\text { Announcement time } \\
\text { Daily: NY Noon }\end{array}$ & $\begin{array}{l}\text { Unit of Measurement } \\
\text { Log Difference }\end{array}$ \\
\hline USA & CPIUS & $\begin{array}{l}\text { Consumer } \\
\text { Inflation }\end{array}$ & 28 & -0.000995 & 0.027769 & Middle/End of month & $\%$ growth year on year \\
\hline SA & PPISA & $\begin{array}{l}\text { Producer Price } \\
\text { Inflation }\end{array}$ & 33 & 0.000498 & 0.150217 & Middle/End of month & $\%$ growth year on year \\
\hline USA & PPIUS & $\begin{array}{l}\text { Producer Price } \\
\text { Inflation }\end{array}$ & 35 & -0.001119 & 0.109618 & Middle/End of month before CPI & $\%$ growth year on year \\
\hline SA & REPO & Interest Rate & 6 & -0.001866 & 0.052901 & Ad Hoc & $\%$ \\
\hline USA & FED & Interest Rate & 2 & 0 & 0.012477 & Ad Hoc & $\%$ \\
\hline USA & NFP & Employment & 37 & -1517.413 & 20090.91 & Beginning of month & Change in actual jobs \\
\hline USA & IND & Output & 30 & -0.001741 & 0.060689 & Middle of month & Monthly \% change \\
\hline SA & GDP & Output & 11 & -0.002736 & 0.060857 & End of month-Quarterly & Quarterly \% growth \\
\hline
\end{tabular}


Table 2: ADF Test Statistics

\begin{tabular}{lll}
\hline Variable & ADF Test Statistic & Critical Value (5\%) \\
\hline DLNER & $-21.1494^{*}$ & -2.8656 \\
CPIXSA & $-28.1995^{*}$ & -2.8655 \\
CPIUS & $-28.2323^{*}$ & -2.8655 \\
PPISA & $-28.1961^{*}$ & -2.8655 \\
PPIUS & $-28.1987^{*}$ & -2.8655 \\
REPO & $-28.2312^{*}$ & -2.8655 \\
FED & $-28.1957^{*}$ & -2.8655 \\
NFP & $-28.3581^{*}$ & -2.8655 \\
IND & $-28.2192^{*}$ & -2.8655 \\
GDP & $-28.2534^{*}$ & -2.8655 \\
TRADESA & $-28.1216^{*}$ & -2.8655 \\
TRADEUS & $-28.2049^{*}$ & -2.8655 \\
M3 & $-28.1115^{*}$ & -2.8655 \\
\hline
\end{tabular}

* denotes rejection of the null of non-stationarity at the $5 \%$ level of significance 
Table 3: Effects of all 'surprises' on daily rand/dollar exchange rate

\begin{tabular}{|c|c|c|c|c|}
\hline & (1) & (2a) & (2b) & (2c) \\
\hline Variable & $\Delta \ln \phi$ & $\Delta \ln \phi$ & $\Delta \ln \phi$ & $\Delta \ln \phi$ \\
\hline $\mathrm{C}$ & $\begin{array}{c}-0.00028 \\
(0.000456)\end{array}$ & $0.0037439^{*}$ & $0.001159 *$ & $0.0034888^{*}$ \\
\hline CPIUS & $0.030106^{* * *}$ & $0.030535^{* * *}$ & $0.031656^{* * *}$ & $0.029212^{* * * *}$ \\
\hline CPIXSA & $\begin{array}{c}(0.016449) \\
0.004456 \\
(0.005555)\end{array}$ & $\begin{array}{c}(0.016283) \\
0.0043700 \\
(0.0054987)\end{array}$ & $\begin{array}{c}0.003941 \\
(0.005554)\end{array}$ & $\begin{array}{c}(0.00048248 \\
0.0048286)\end{array}$ \\
\hline PPIUS & $\begin{array}{l}-0.00846^{* *} \\
(0.004145)\end{array}$ & $\begin{array}{c}-0.0074585 * * * \\
(0.0041107)\end{array}$ & $\begin{array}{c}-0.00792 * * * \\
(0.00415)\end{array}$ & $\begin{array}{c}-0.0076875^{* * *} * \\
(0.0041132)\end{array}$ \\
\hline PPISA & $\begin{array}{c}-0.00028 \\
(0.003106)\end{array}$ & $\begin{array}{c}-0.6171 \mathrm{E}-3 \\
(0.0030753)\end{array}$ & $\begin{array}{c}-0.00066 \\
(0.003109)\end{array}$ & $\begin{array}{l}-0.3541 \mathrm{E}-3 \\
(0.0030813)\end{array}$ \\
\hline TRADEUS & $\begin{array}{l}-2.06 \mathrm{E}-07 \\
(8.64 \mathrm{E}-07)\end{array}$ & $\begin{array}{l}-0.4412 \mathrm{E}-6 \\
(0.8573 \mathrm{E}-6)\end{array}$ & $\begin{array}{l}-2.93 \mathrm{E}-07 \\
(8.64 \mathrm{E}-07)\end{array}$ & $\begin{array}{l}-0.4237 \mathrm{E}-6 \\
(0.8571 \mathrm{E}-6)\end{array}$ \\
\hline TRADESA & $\begin{array}{c}2.27 \mathrm{E}-07 \\
(8.57 \mathrm{E}-07)\end{array}$ & $\begin{array}{c}0.2347 \mathrm{E}-6 \\
(0.8487 \mathrm{E}-6)\end{array}$ & $\begin{array}{c}1.89 \mathrm{E}-07 \\
(8.56 \mathrm{E}-07)\end{array}$ & $\begin{array}{c}0.2720 \mathrm{E}-6 \\
(0.8489 \mathrm{E}-6)\end{array}$ \\
\hline NFP & $\begin{array}{l}1.20 \mathrm{E}-08 \\
(2.25 \mathrm{E}-08)\end{array}$ & $\begin{array}{c}0.1631 \mathrm{E}-7 \\
(0.2233 \mathrm{E}-7)\end{array}$ & $\begin{array}{l}1.39 \mathrm{E}-08 \\
(2.25 \mathrm{E}-08)\end{array}$ & $\begin{array}{c}0.1577 \mathrm{E}-7 \\
(0.2233 \mathrm{E}-7)\end{array}$ \\
\hline IND & $\begin{array}{c}0.018357^{* *} \\
(0.007544)\end{array}$ & $\begin{array}{c}0.019542 * \\
(0.0074733)\end{array}$ & $\begin{array}{c}0.019143 * * \\
(0.007546)\end{array}$ & $\begin{array}{l}0.019131 * * \\
(0.0074777)\end{array}$ \\
\hline GDP & $\begin{array}{c}-0.00134 \\
(0.007442)\end{array}$ & $\begin{array}{l}-0.0014857 \\
(0.0073665)\end{array}$ & $\begin{array}{c}-0.00226 \\
(0.007449)\end{array}$ & $\begin{array}{c}-0.6739 \mathrm{E}-3 \\
(0.0073921)\end{array}$ \\
\hline M3 & $\begin{array}{c}0.00188 \\
(0.001592)\end{array}$ & $\begin{array}{c}0.0017972 \\
(0.0015759)\end{array}$ & $\begin{array}{c}0.001727 \\
(0.001592)\end{array}$ & $\begin{array}{c}0.0019165 \\
(0.0015781)\end{array}$ \\
\hline FED & $\begin{array}{l}-0.02759 \\
(0.037314)\end{array}$ & $\begin{array}{l}-0.028550 \\
(0.036938)\end{array}$ & $\begin{array}{c}-0.02749 \\
(0.037262)\end{array}$ & $\begin{array}{l}-0.028900 \\
(0.036926)\end{array}$ \\
\hline REPO & $\begin{array}{c}-0.00051 \\
(0.008574)\end{array}$ & $\begin{array}{c}0.0020901 \\
(0.0085109)\end{array}$ & $\begin{array}{c}0.000232 \\
(0.008572)\end{array}$ & $\begin{array}{c}0.0020977 \\
(0.0085078)\end{array}$ \\
\hline DUMMY 20/12/2001 & - & $\begin{array}{l}-0.0048858^{*} \\
(0.0011783)\end{array}$ & - & $\begin{array}{l}-0.0061960^{*} \\
(0.0015734)\end{array}$ \\
\hline TIME TREND & - & - & $\begin{array}{c}-3.55 \mathrm{E}-06^{* * *} \\
(1.98 \mathrm{E}-06)\end{array}$ & $\begin{array}{c}0.3294 \mathrm{E}-5 \\
(0.2622 \mathrm{E}-5)\end{array}$ \\
\hline ADJ $R^{2}$ & 0.004734 & 0.024724 & 0.007517 & 0.025438 \\
\hline PROB (F-STATISTIC) & 0.202591 & 0.002 & 0.123776 & 0.002 \\
\hline AUTOCORRELATION & $\begin{array}{l}0.62665 \\
{[0.429]}\end{array}$ & $\begin{array}{l}1.4091 \\
{[0.235]}\end{array}$ & $\begin{array}{l}0.77525 \\
{[0.379]}\end{array}$ & $\begin{array}{l}1.4632 \\
{[0.226]}\end{array}$ \\
\hline RESET & $\begin{array}{l}1.7100 \\
{[0.191]}\end{array}$ & $\begin{array}{l}1.4765 \\
{[0.224]}\end{array}$ & $\begin{array}{l}1.9833 \\
{[0.159]}\end{array}$ & $\begin{array}{l}1.5029 \\
{[0.220]}\end{array}$ \\
\hline HETEROSCEDASTICITY & $\begin{array}{l}2.8900 \\
{[0.089]}\end{array}$ & $\begin{array}{l}2.3907 \\
{[0.122]}\end{array}$ & $\begin{array}{l}2.9962 \\
{[0.083]}\end{array}$ & $\begin{array}{l}3.1252 \\
{[0.077]}\end{array}$ \\
\hline
\end{tabular}

Figures in round parentheses denote standard errors: figures in square parentheses denote probability levels; * denotes significance at the $1 \%,{ }^{* \star}$ at the $5 \%$ and ${ }^{\star \star \star}$ at the $10 \%$ level of significance 
Table 4: Nonlinear variables, lags and variable specific dummies

\begin{tabular}{|c|c|c|c|c|c|c|c|}
\hline & (1a) & (1b) & & (2a) & (2b) & & (3) \\
\hline Variable & $\Delta \ln \phi$ & $\Delta \ln \phi$ & Variable & $\Delta \ln \phi$ & $\Delta \ln \phi$ & Variable & $\Delta \ln \phi$ \\
\hline $\mathrm{C}$ & $\begin{array}{c}-0.00028 \\
(0.000454)\end{array}$ & $\begin{array}{c}-0.2946 \mathrm{E}-3 \\
(0.4556 \mathrm{E}-3)\end{array}$ & $\mathrm{C}$ & $\begin{array}{l}-0.000356 \\
(0.00046)\end{array}$ & $\begin{array}{c}-0.00047 \\
(0.000469)\end{array}$ & $\mathrm{C}$ & $\begin{array}{c}-0.00055 \\
(0.000544)\end{array}$ \\
\hline CPIUS & & $\begin{array}{l}0.11113 * * \\
(0.045415)\end{array}$ & CPIUS & $\begin{array}{c}0.030536 * * * \\
(0.01665)\end{array}$ & $\begin{array}{c}0.027113 \\
(0.017006)\end{array}$ & CPIUSG & $\begin{array}{c}-0.00408 \\
(0.003418)\end{array}$ \\
\hline CPIUS $^{2}$ & $\begin{array}{c}0.080623 \\
(0.077585)\end{array}$ & $\begin{array}{c}-0.4025 * * * \\
(0.2128)\end{array}$ & CPIUS(-1) & $\begin{array}{r}-0.007768 \\
(0.01661)\end{array}$ & $\begin{array}{c}-0.00298 \\
(0.016777)\end{array}$ & CPIUSB & $\begin{array}{c}0.003046 \\
(0.003915)\end{array}$ \\
\hline CPIXSA & & $\begin{array}{c}-0.0035112 \\
(0.011111)\end{array}$ & CPIUS(-2) & & $\begin{array}{c}-0.02946 * * * \\
(0.016965)\end{array}$ & CPIXSAG & $\begin{array}{c}0.002927 \\
(0.003799)\end{array}$ \\
\hline CPIXSA $^{2}$ & $\begin{array}{c}0.004597 \\
(0.003894)\end{array}$ & $\begin{array}{c}0.0057381 \\
(0.0076385)\end{array}$ & CPIUS(-3) & & $\begin{array}{c}-0.03746^{* *} \\
(0.016849)\end{array}$ & CPIXSAB & $\begin{array}{c}0.003036 \\
(0.003031)\end{array}$ \\
\hline PPIUS & & $\begin{array}{l}0.029909 * \\
(0.011103)\end{array}$ & CPIXSA & $\begin{array}{c}0.004382 \\
(0.005596)\end{array}$ & $\begin{array}{c}0.00555 \\
(0.00573)\end{array}$ & PPIUSG & $\begin{array}{c}0.003476 \\
(0.003215)\end{array}$ \\
\hline PPIUS $^{2}$ & $\begin{array}{l}-0.01355^{*} \\
(0.004235)\end{array}$ & $\begin{array}{l}-0.042023^{*} \\
(0.011363)\end{array}$ & CPIXSA(-1) & $\begin{array}{c}0.004258 \\
(0.005583)\end{array}$ & $\begin{array}{c}0.003317 \\
(0.005687)\end{array}$ & PPIUSB & $\begin{array}{c}0.002103 \\
(0.003201)\end{array}$ \\
\hline PPISA & & $\begin{array}{c}-0.0014575 \\
(0.0062470)\end{array}$ & CPIXSA(-2) & & $\begin{array}{c}-0.0042 \\
(0.005608)\end{array}$ & PPISAG & $\begin{array}{c}-0.00014 \\
(0.003015)\end{array}$ \\
\hline PPISA $^{2}$ & $\begin{array}{c}1.79 \mathrm{E}-05 \\
(0.001632)\end{array}$ & $\begin{array}{c}0.6814 \mathrm{E}-3 \\
(0.0032923)\end{array}$ & CPIXSA(-3) & & $\begin{array}{c}-0.0063 \\
(0.00561)\end{array}$ & PPISAB & $\begin{array}{c}-0.00256 \\
(0.003612)\end{array}$ \\
\hline TRADEUS & & $\begin{array}{l}-0.1682 \mathrm{E}-5 \\
(0.2450 \mathrm{E}-5)\end{array}$ & PPIUS & $\begin{array}{c}-0.008678 * * \\
(0.004165)\end{array}$ & $\begin{array}{c}-0.00814 * * * \\
(0.004172)\end{array}$ & TRADEUSG & $\begin{array}{c}0.000685 \\
(0.003281)\end{array}$ \\
\hline TRADEUS $^{2}$ & $\begin{array}{l}-2.88 \mathrm{E}-11 \\
(2.12 \mathrm{E}-10)\end{array}$ & $\begin{array}{l}0.3107 \mathrm{E}-9 \\
(0.6027 \mathrm{E}-9)\end{array}$ & PPIUS(-1) & $\begin{array}{l}-0.002751 \\
(0.004180)\end{array}$ & $\begin{array}{c}-0.00236 \\
(0.004192)\end{array}$ & TRADEUSB & $\begin{array}{c}0.001149 \\
(0.003027)\end{array}$ \\
\hline TRADESA & & $\begin{array}{l}0.6781 \mathrm{E}-6 \\
(0.2198 \mathrm{E}-5)\end{array}$ & PPIUS(-2) & & $\begin{array}{c}-0.00877 * * \\
(0.004216)\end{array}$ & TRADESAG & $\begin{array}{c}0.000461 \\
(0.003035)\end{array}$ \\
\hline TRADESA $^{2}$ & $\begin{array}{c}4.02 \mathrm{E}-11 \\
(2.02 \mathrm{E}-10)\end{array}$ & $\begin{array}{l}-0.1169 \mathrm{E}-9 \\
(0.5207 \mathrm{E}-9)\end{array}$ & PPIUS(-3) & & $\begin{array}{c}0.004054 \\
(0.004224)\end{array}$ & TRADESAB & $\begin{array}{c}-0.00211 \\
(0.003441)\end{array}$ \\
\hline NFP & & $\begin{array}{l}0.1198 \mathrm{E}-7 \\
(0.2241 \mathrm{E}-7)\end{array}$ & PPISA & $\begin{array}{c}-0.000585 \\
(0.003330)\end{array}$ & $\begin{array}{c}-0.00012 \\
(0.003342)\end{array}$ & INDG & $\begin{array}{c}0.008309 \\
(0.003851)\end{array}$ \\
\hline $\mathrm{NFP}^{2}$ & $\begin{array}{c}9.65 \mathrm{E}-14 \\
(1.09 \mathrm{E}-13)\end{array}$ & $\mathrm{n} / \mathrm{a}$ & PPISA(-1) & $\begin{array}{c}0.002687 \\
(0.003121)\end{array}$ & $\begin{array}{c}0.00373 \\
(0.003342)\end{array}$ & INDB & $\begin{array}{c}-0.00105 \\
(0.003286)\end{array}$ \\
\hline IND & & $\begin{array}{l}0.0077753 \\
(0.029274)\end{array}$ & PPISA(-2) & & $\begin{array}{c}-0.00206 \\
(0.003424)\end{array}$ & NFPG & $\begin{array}{c}0.004355 \\
(0.003483)\end{array}$ \\
\hline $\mathrm{IND}^{2}$ & $\begin{array}{c}0.041618 * * \\
(0.018286)\end{array}$ & $\begin{array}{c}0.025660 \\
(0.071138)\end{array}$ & PPISA(-3) & & $\begin{array}{c}-0.0026 \\
(0.003199)\end{array}$ & NFPB & $\begin{array}{c}0.003222 \\
(0.002798)\end{array}$ \\
\hline GDP & & $\begin{array}{c}-0.016946 \\
(0.024810)\end{array}$ & IND & $\begin{array}{l}0.019862 * \\
(0.007683)\end{array}$ & $\begin{array}{c}0.018929 * * \\
(0.00781)\end{array}$ & GDPG & $\begin{array}{c}-0.00481 \\
(0.006459)\end{array}$ \\
\hline $\mathrm{GDP}^{2}$ & $\begin{array}{l}3.74 \mathrm{E}-05 \\
(0.00836)\end{array}$ & $\begin{array}{c}0.018227 \\
(0.027946)\end{array}$ & $\operatorname{IND}(-1)$ & $\begin{array}{c}-0.002432 \\
(0.007582)\end{array}$ & $\begin{array}{c}-0.00184 \\
(0.007798)\end{array}$ & GDPB & $\begin{array}{c}-0.00097 \\
(0.00491)\end{array}$ \\
\hline M3 & & $\begin{array}{c}0.0019206 \\
(0.0044855)\end{array}$ & $\mathrm{IND}(-2)$ & & $\begin{array}{c}-2.97 \mathrm{E}-05 \\
(0.007714)\end{array}$ & $\mathrm{M} 3 \mathrm{G}$ & $\begin{array}{c}-0.00451 \\
(0.003227)\end{array}$ \\
\hline $\mathrm{M}^{2}$ & $\begin{array}{c}0.000885 \\
(0.000712)\end{array}$ & $\begin{array}{c}0.1390 \mathrm{E}-3 \\
(0.0019576)\end{array}$ & $\operatorname{IND}(-3)$ & & $\begin{array}{c}-0.00287 \\
(0.007629)\end{array}$ & M3B & $\begin{array}{c}-0.00079 \\
(0.003155)\end{array}$ \\
\hline FED & & $\begin{array}{l}-0.028232 \\
(0.037183)\end{array}$ & NFP & $\begin{array}{c}1.16 \mathrm{E}-08 \\
(2.26 \mathrm{E}-08)\end{array}$ & $\begin{array}{c}1.16 \mathrm{E}-08 \\
(2.27 \mathrm{E}-08)\end{array}$ & FEDG & $\begin{array}{c}-0.01474 \\
(0.013214)\end{array}$ \\
\hline FED $^{2}$ & $\begin{array}{c}-0.10701 \\
(0.146967)\end{array}$ & $\mathrm{n} / \mathrm{a}$ & NFP(-1) & $\begin{array}{l}-2.62 \mathrm{E}-08 \\
(2.26 \mathrm{E}-08)\end{array}$ & $\begin{array}{l}-3.01 \mathrm{E}-08 \\
(2.27 \mathrm{E}-08)\end{array}$ & FEDB & $\begin{array}{c}-0.00147 \\
(0.012885)\end{array}$ \\
\hline REPO & & $\begin{array}{l}0.3405 E-3 \\
(0.014410)\end{array}$ & NFP(-2) & & $\begin{array}{c}-2.19 \mathrm{E}-08 \\
(2.26 \mathrm{E}-08)\end{array}$ & REPOG & $\begin{array}{c}-0.01361 \\
(0.007452)\end{array}$ \\
\hline \multirow[t]{11}{*}{$\mathrm{REPO}^{2}$} & $\begin{array}{l}0.000966 \\
(0.01117)\end{array}$ & $\begin{array}{l}-0.0042881 \\
(0.018896)\end{array}$ & NFP(-3) & & $\begin{array}{l}-2.95 \mathrm{E}-08 \\
(2.29 \mathrm{E}-08)\end{array}$ & REPOB & $\begin{array}{c}-0.00135 \\
(0.007629)\end{array}$ \\
\hline & & & GDP & $\begin{array}{c}-0.001397 \\
(0.007468)\end{array}$ & $\begin{array}{c}-0.00303 \\
(0.007576)\end{array}$ & & \\
\hline & & & GDP(-1) & $\begin{array}{c}0.002493 \\
(0.007987)\end{array}$ & $\begin{array}{c}6.08 \mathrm{E}-05 \\
(0.008055)\end{array}$ & & \\
\hline & & & GDP(-2) & & $\begin{array}{l}-0.00572 \\
(0.00801)\end{array}$ & & \\
\hline & & & GDP(-3) & & $\begin{array}{c}0.001389 \\
(0.008285)\end{array}$ & & \\
\hline & & & M3 & $\begin{array}{c}0.001930 \\
(0.001605)\end{array}$ & $\begin{array}{c}0.002285 \\
(0.001644)\end{array}$ & & \\
\hline & & & M3(-1) & $\begin{array}{c}0.000918 \\
(0.001606)\end{array}$ & $\begin{array}{c}0.000773 \\
(0.001649)\end{array}$ & & \\
\hline & & & M3(-2) & & $\begin{array}{c}-0.0002 \\
(0.001614)\end{array}$ & & \\
\hline & & & M3(-3) & & $\begin{array}{l}-0.00085 \\
(0.00161)\end{array}$ & & \\
\hline & & & TRADEUS & $\begin{array}{c}-2.16 \mathrm{E}-07 \\
(8.70 \mathrm{E}-07)\end{array}$ & $\begin{array}{c}-5.37 \mathrm{E}-07 \\
(8.87 \mathrm{E}-07)\end{array}$ & & \\
\hline & & & TRADEUS(-1) & $\begin{array}{c}9.90 \mathrm{E}-07 \\
(8.69 \mathrm{E}-07)\end{array}$ & $\begin{array}{c}9.98 \mathrm{E}-07 \\
(8.72 \mathrm{E}-07)\end{array}$ & & \\
\hline
\end{tabular}




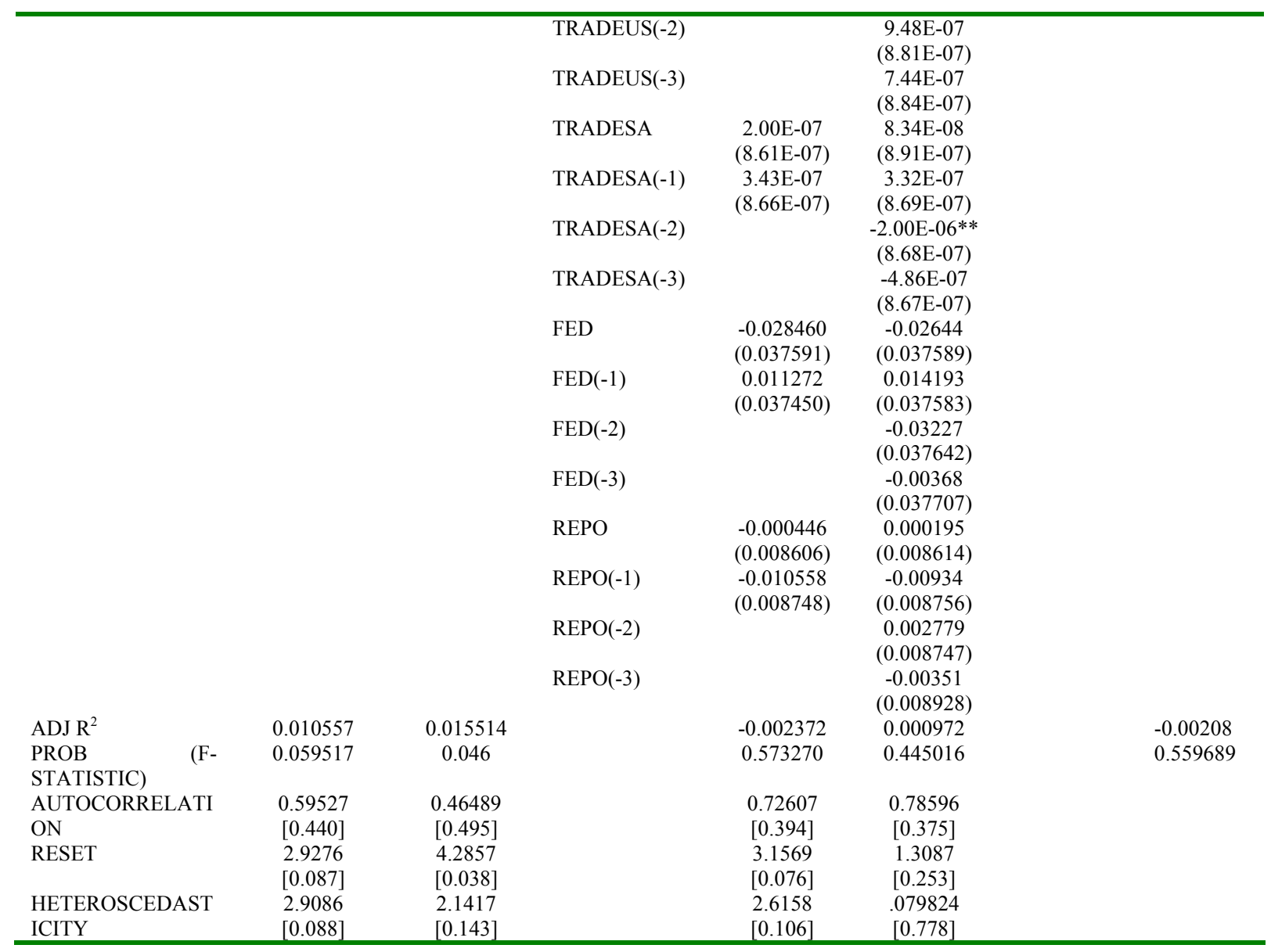

Figures in round parentheses denote standard errors: figures in square parentheses denote probability levels: $*$ denotes significance at the $1 \%,{ }^{* *}$ at the $5 \%$ and $* * *$ at the $10 \%$ level of significance 
Table 5: Time Varying Effects

\begin{tabular}{|c|c|c|c|c|c|c|c|c|c|c|c|}
\hline & (1a) & (1b) & (1c) & & (2a) & (2b) & (2c) & (2d) & (2e) & (2f) & 2(g) \\
\hline Variable & $\Delta \ln \phi$ & $\Delta \ln \phi$ & $\Delta \ln \phi$ & Variable & $\Delta \ln \phi$ & $\Delta \ln \phi$ & $\Delta \ln \phi$ & $\Delta \ln \phi$ & $\Delta \ln \phi$ & $\Delta \ln \phi$ & $\Delta \ln ($ \\
\hline C & $\begin{array}{c}0.000448 \\
(0.000661)\end{array}$ & $\begin{array}{c}-0.000817 \\
(0.000716)\end{array}$ & $\begin{array}{c}-0.000871 \\
(0.000789)\end{array}$ & C & $\begin{array}{c}-0.00065 \\
(0.000536)\end{array}$ & $\begin{array}{c}0.001239 \\
(0.001355)\end{array}$ & $\begin{array}{c}-0.000468 \\
(0.001273)\end{array}$ & $\begin{array}{c}-0.001449 \\
(0.001064)\end{array}$ & $\begin{array}{c}-0.001397 \\
(0.001403)\end{array}$ & $\begin{array}{c}-0.000769 \\
(0.001141)\end{array}$ & $\begin{array}{l}-0.001087 \\
(0.00154)\end{array}$ \\
\hline CPIUS & $\begin{array}{c}0.035264 \\
(0.023492)\end{array}$ & $\begin{array}{c}0.095234^{*} \\
(0.034478)\end{array}$ & $\begin{array}{c}0.004275 \\
(0.027038)\end{array}$ & USG & $\begin{array}{c}0.002976 \\
(0.001634)\end{array}$ & $\begin{array}{c}0.007721 \\
(0.004965)\end{array}$ & $\begin{array}{c}-0.005270 \\
(0.003296)\end{array}$ & $\begin{array}{c}-0.000152 \\
(0.003209)\end{array}$ & $\begin{array}{c}0.010749 * \\
(0.003916)\end{array}$ & $\begin{array}{c}0.000604 \\
(0.003805)\end{array}$ & $\begin{array}{l}0.007108 \\
(0.005067)\end{array}$ \\
\hline CPIXSA & $\begin{array}{c}0.009820 \\
(0.012906)\end{array}$ & $\begin{array}{c}0.005198 \\
(0.006295)\end{array}$ & $\begin{array}{c}0.003865 \\
(0.007714)\end{array}$ & USB & $\begin{array}{c}0.002163 \\
(0.001523)\end{array}$ & $\begin{array}{c}0.004903 \\
(0.004075)\end{array}$ & $\begin{array}{c}0.006601 \\
(0.004254)\end{array}$ & $\begin{array}{c}-0.000884 \\
(0.002996)\end{array}$ & $\begin{array}{c}-0.000393 \\
(0.003728)\end{array}$ & $\begin{array}{c}0.003873 \\
(0.003493)\end{array}$ & $\begin{array}{l}0.000292 \\
(0.003840)\end{array}$ \\
\hline PPIUS & $\begin{array}{c}0.001349 \\
(0.006389)\end{array}$ & $\begin{array}{c}- \\
0.017062 * \\
(0.004973)\end{array}$ & $\begin{array}{c}0.010345 \\
(0.012635)\end{array}$ & SAG & $\begin{array}{c}-0.00215 \\
(0.001642)\end{array}$ & $\begin{array}{c}0.001734 \\
(0.004273)\end{array}$ & $\begin{array}{l}-0.006132 \\
(0.004052)\end{array}$ & $\begin{array}{l}0.001042 \\
0.003367\end{array}$ & $\begin{array}{c}-.006921^{* * *} \\
(0.003684)\end{array}$ & $\begin{array}{l}-0.001989 \\
(0.004165)\end{array}$ & $\begin{array}{l}0.000975 \\
(0.004649)\end{array}$ \\
\hline PPISA & $\begin{array}{l}-0.002214 \\
(0.003718)\end{array}$ & $\begin{array}{l}-0.001367 \\
(0.005683)\end{array}$ & $\begin{array}{c}0.004318 \\
(0.008406)\end{array}$ & SAB & $\begin{array}{c}0.000285 \\
(0.001583)\end{array}$ & $\begin{array}{c}0.003313 \\
(0.003639)\end{array}$ & $\begin{array}{c}0.000253 \\
(0.004037)\end{array}$ & $\begin{array}{c}-0.001619 \\
0.002982\end{array}$ & $\begin{array}{c}0.002049 \\
(0.004880)\end{array}$ & $\begin{array}{l}-0.004191 \\
(0.003455)\end{array}$ & $\begin{array}{l}-0.001046 \\
(0.004649)\end{array}$ \\
\hline TRADEUS & $\begin{array}{c}-1.10 \mathrm{E}-07 \\
(1.19 \mathrm{E}-06)\end{array}$ & $\begin{array}{c}-2.87 \mathrm{E}-06 * * \\
(1.29 \mathrm{E}-06)\end{array}$ & $\begin{array}{c}1.56 \mathrm{E}-06 \\
(1.77 \mathrm{E}-06)\end{array}$ & & & & & & & & \\
\hline TRADESA & $\begin{array}{c}-2.43 \mathrm{E}-07 \\
(1.33 \mathrm{E}-06)\end{array}$ & $\begin{array}{c}3.51 \mathrm{E}-07 \\
(1.71 \mathrm{E}-06)\end{array}$ & $\begin{array}{c}1.02 \mathrm{E}-06 \\
(1.22 \mathrm{E}-06)\end{array}$ & & & & & & & & \\
\hline NFP & $\begin{array}{l}-5.39 \mathrm{E}-08 \\
(4.71 \mathrm{E}-08)\end{array}$ & $\begin{array}{c}3.83 \mathrm{E}-08 \\
(3.14 \mathrm{E}-08)\end{array}$ & $\begin{array}{c}2.54 \mathrm{E}-08 \\
(3.75 \mathrm{E}-08)\end{array}$ & & & & & & & & \\
\hline IND & $\begin{array}{l}0.032665^{*} \\
(0.011348)\end{array}$ & $\begin{array}{c}0.016422 \\
(0.010639)\end{array}$ & $\begin{array}{c}0.009882 \\
(0.012980)\end{array}$ & & & & & & & & \\
\hline GDP & $\begin{array}{l}-0.012765 \\
(0.013770)\end{array}$ & $\begin{array}{l}-0.030552 \\
(0.023152)\end{array}$ & $\begin{array}{c}0.006198 \\
(0.009523)\end{array}$ & & & & & & & & \\
\hline M3 & $\begin{array}{c}0.000564 \\
(0.002116)\end{array}$ & $\begin{array}{c}0.002179 \\
(0.002415)\end{array}$ & $\begin{array}{c}0.001371 \\
(0.003170)\end{array}$ & & & & & & & & \\
\hline FED & $\begin{array}{c}0.009859 \\
(0.050209)\end{array}$ & $\begin{array}{l}-0.030650 \\
(0.036911)\end{array}$ & $\begin{array}{l}-0.034045 \\
(0.070230)\end{array}$ & & & & & & & & \\
\hline REPO & $\begin{array}{l}-0.001573 \\
(0.010276)\end{array}$ & $\begin{array}{c}0.004176 \\
(0.016653)\end{array}$ & $\begin{array}{c}-0.002153 \\
0.015184\end{array}$ & & & & & & & & \\
\hline ADJ $R^{2}$ & 0.005941 & 0.062900 & -0.022433 & & 0.005265 & 0.011331 & 0.017276 & -0.027956 & 0.057222 & -0.004105 & -0.014855 \\
\hline $\begin{array}{l}\text { PROB (F- } \\
\text { STATISTIC) }\end{array}$ & 0.286852 & 0.003043 & 0.924177 & & 0.084636 & 0.227984 & 0.188466 & 0.971320 & 0.023065 & 0.485144 & 0.715387 \\
\hline
\end{tabular}

Figures in round parentheses denote standard errors; figures in square parentheses denote probability levels; * denotes significance at the $1 \%$, ${ }^{\star \star}$ at the $5 \%$ and $* * *$ at the $10 \%$ level of significance 